\title{
Treatment of cheese whey wastewater by combined electrochemical processes
}

\author{
Lydia Tirado $^{1}$. Ömür Gökkuş ${ }^{2}$ Enric Brillas ${ }^{1} \cdot$ Ignasi Sirés $^{1}$
}

Received: 27 March 2018 / Accepted: 29 May 2018

(c) Springer Science+Business Media B.V., part of Springer Nature 2018

\begin{abstract}
This study shows the good performance of a sequential electrochemical methodology, consisting in electrocoagulation (EC) followed by an electrochemical advanced oxidation process (EAOP), to treat raw cheese whey wastewater at laboratory and pre-pilot scales. In EC, different electrode materials like Fe, Al and stainless steel (AISI 304 and ASI 316L) were tested. Among EAOPs, photoelectro-Fenton (PEF) and electrochemical oxidation (EO) with active anodes like Pt or DSA ${ }^{\circledR}$ and non-active ones like boron-doped diamond (BDD) were studied. At both scales, the optimum anode/cathode combination in EC was Fe/AISI 304, which yielded the highest total organic carbon (TOC) removal of 22.0-27.0\%. This is due to various effects on organic compounds: (i) coagulation promoted by $\mathrm{Fe}(\mathrm{OH})_{3}$ flocs, (ii) cathodic reduction, and (iii) oxidation with generated active chlorine. At small scale, the resulting wastewater was further treated by PEF at $\mathrm{pH} 3.0$. The highest TOC removal was achieved using the BDD, owing to the great oxidation power of hydroxyl radicals. In contrast, total nitrogen was abated much more rapidly with active anodes because of the attack of active chlorine on N-compounds. At pre-pilot scale, the post-treatment of conditioned wastewater made by EO with a BDD/Pt flow cell combined with UVA irradiation yielded the highest TOC removal, i.e., 49.1\%. The high energy consumed by the UVA lamp would be a drawback at industrial scale, which could be overcome by using sunlight.
\end{abstract}

\section{Graphical Abstract}

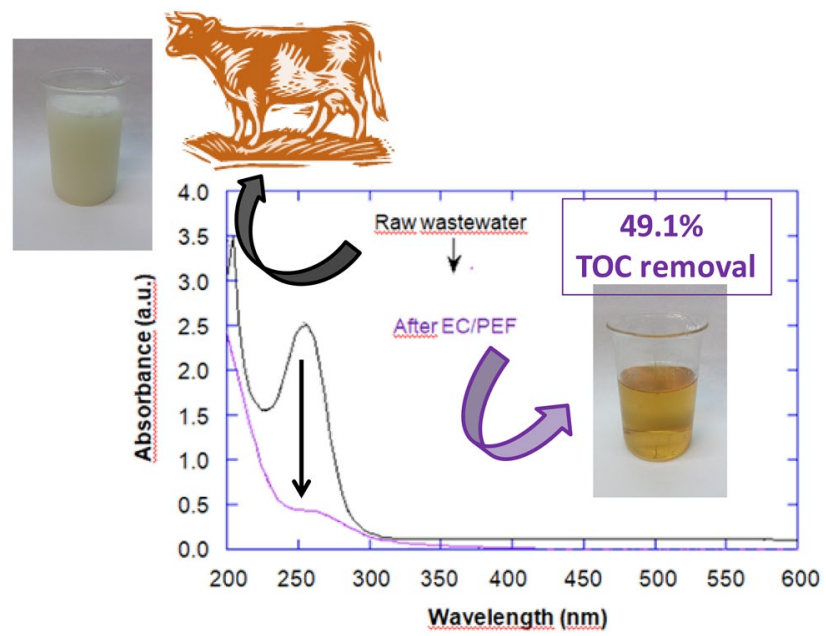

Keywords Boron-doped diamond - Cheese whey wastewater · Dimensionally stable anode $\cdot$ Electrochemical oxidation . Electrocoagulation $\cdot$ Photoelectro-Fenton

Ignasi Sirés

i.sires@ub.edu

Extended author information available on the last page of the article 


\section{Introduction}

The dairy industry, as is typical in the agri-food sector, requires large volumes of water. Studies on the water footprint of animal products estimate that up to $1000 \mathrm{~L}$ of $\mathrm{H}_{2} \mathrm{O}$ are necessary to produce $1 \mathrm{~L}$ of milk [1]. As a result, this sector generates huge amount of wastewater, around $0.2-10 \mathrm{~L}$ per liter of processed milk [2]. Dairy wastewater is characterized by high organic matter content, hardly biodegradable and with tendency to form colloidal suspensions [1], which can damage the natural water streams in the event of inadequate handling [3]. Its composition includes pollutants that result from the processed raw materials, chemicals, and technological additives. Hence, when these effluents are discharged into rivers, they contribute to eutrophication due to the surplus of nutrients like phosphorus and N-compounds. Treating dairy effluents is of crucial importance not only for environmental preservation, but also for water reuse in industrial processes [2]. In recent years, the regulations have become more stringent and thus, to stay in compliance with the discharge limits is becoming a burden for most dairies [4-6].

Anaerobic biological methods are popular to treat dairy effluents [4, 7-11], despite the long times required to ensure a good performance. Physicochemical methods such as coagulation and adsorption [6, 12], as well as chemical processes [13], have been employed as well. The former methods can only transfer the contaminants between different phases, whereas the second ones are able to destroy them, eventually leading to high removal of chemical oxygen demand (COD) and total organic carbon (TOC). Greater effectiveness has been achieved by means of electrochemical technologies. However, little information is still available on their use, being limited to either single electrocoagulation (EC) with $\mathrm{Fe}$ or $\mathrm{Al}$ anodes [14-19], EC coupled with chemical Fenton and ozonation [20] and electro-oxidation (EO) with Pt [21] or dimensionally stables anodes $\left(\mathrm{DSA}^{\circledR}\right)[3,22]$. More research is then needed to clarify the feasibility of sequential electrochemical processes for treating cheese whey wastewater.

Lately, EC and several electrochemical advanced oxidation processes (EAOPs) are receiving great attention for the removal of organic pollutants from water because they allow efficient decontamination in compact reactors at moderate costs [23-26]. EC, an alternative phase separation method to chemical coagulation, is a traditional electrochemical technology based on the release of $\mathrm{Fe}^{2+}$ or $\mathrm{Al}^{3+}$ cations from dissolution of a sacrificial $\mathrm{Fe}$ or $\mathrm{Al}$ anode, respectively, as follows $[25,27-30]$ :

$\mathrm{Fe}_{(\mathrm{s})} \rightarrow \mathrm{Fe}^{2+}{ }_{(\text {aq })}+2 \mathrm{e}^{-}$

$\mathrm{Al}_{(\mathrm{s})} \rightarrow \mathrm{Al}^{3+}{ }_{(\mathrm{aq})}+3 \mathrm{e}^{-}$
Simultaneously, the cathode generates $\mathrm{H}_{2}$ bubbles and $\mathrm{OH}^{-}$anions. This leads to the formation of active coagulants such as insoluble metal hydroxides by reactions (3) and (4). Flocs are formed, being aggregated in particles of large surface area that remain as a gelatinous suspension able to remove pollutants by coagulation, whereas $\mathrm{H}_{2}$ gas promotes flotation of the aggregates.

$4 \mathrm{Fe}^{2+}{ }_{(\mathrm{aq})}+10 \mathrm{H}_{2} \mathrm{O}+\mathrm{O}_{2(\mathrm{~g})} \rightarrow 4 \mathrm{Fe}(\mathrm{OH})_{3(\mathrm{~s})}+8 \mathrm{H}^{+}$

$\mathrm{Al}^{3+}{ }_{(\mathrm{aq})}+3 \mathrm{H}_{2} \mathrm{O} \rightarrow \mathrm{Al}(\mathrm{OH})_{3(\mathrm{~s})}+3 \mathrm{H}^{+}$

The electrolytic dissolution of Fe anode produces insoluble flocs of $\mathrm{Fe}(\mathrm{OH})_{2}$ at $\mathrm{pH}>9$ and $\mathrm{Fe}(\mathrm{OH})_{3}$ at $\mathrm{pH}>3$ in the presence of dissolved $\mathrm{O}_{2}$ gas from reaction (3) [25]. On the other hand, the $\mathrm{Al}(\mathrm{OH})_{3}$ flocs can also polymerize to $\mathrm{Al}_{\mathrm{n}}(\mathrm{OH})_{3 \mathrm{n}}$ species.

The effectiveness of EAOPs for the degradation of organic pollutants is due to the generation of hydroxyl radicals $\left({ }^{\circ} \mathrm{OH}\right)$ on site. They include EO, electro-Fenton (EF) and photoelectro-Fenton (PEF) as main technologies. EO is the most popular EAOP, in which pollutants are destroyed in an undivided electrolytic cell via direct oxidation at the anode $\mathrm{M}$, at high current, pre-eminently by indirect mediated oxidation with physisorbed hydroxyl radicals $\left(\mathrm{M}\left({ }^{\bullet} \mathrm{OH}\right)\right)$ formed at the anode surface from water oxidation via reaction (5) [23, 24]:

$\mathrm{M}+\mathrm{H}_{2} \mathrm{O} \rightarrow \mathrm{M}\left({ }^{\circ} \mathrm{OH}\right)+\mathrm{H}^{+}+\mathrm{e}^{-}$

Non-active and active anodes show different ability to produce $\mathrm{M}\left({ }^{\bullet} \mathrm{OH}\right)[23,31-34]$. The best non-active anodes are boron-doped diamond (BDD) thin films, which yield much larger amounts of $\mathrm{M}\left({ }^{\bullet} \mathrm{OH}\right)$ as compared to active anodes like Pt and DSA ${ }^{\circledR}$. The latter anodes possess lower $\mathrm{O}_{2}$-evolution overpotential and higher $\mathrm{M}--^{\bullet} \mathrm{OH}$ interaction, leading to a significant transformation of $\mathrm{M}\left({ }^{\bullet} \mathrm{OH}\right)$ into weak chemisorbed oxidant MO [23-25].

The EF and PEF processes are based on the in situ generation of $\mathrm{H}_{2} \mathrm{O}_{2}$ from $\mathrm{O}_{2}$ gas reduction by reaction (6), which is very effective using carbonaceous cathodes such as carbon felt [35-38], or carbon-polytetrafluoroethylene (PTFE) in air-diffusion devices [31-33]. The presence or addition of a catalytic quantity $(0.1-1.0 \mathrm{mM})$ of $\mathrm{Fe}^{2+}$ allows a high production of homogeneous ${ }^{\bullet} \mathrm{OH}$ radicals following Fenton's reaction (7), optimal at $\mathrm{pH} \sim 3$. Moreover, the cathodic regeneration of $\mathrm{Fe}^{2+}$ from $\mathrm{Fe}^{3+}$ reduction ensures the maximum production of ${ }^{\bullet} \mathrm{OH}$ in the bulk. In an undivided cell, organic pollutants are attacked by both strong oxidants, $\mathrm{M}\left({ }^{\bullet} \mathrm{OH}\right)$ and ${ }^{\bullet} \mathrm{OH}$. The PEF process involves the solution irradiation with UVA light [24, 39, 40], whose action is quite complex. Photons can prevent the large accumulation of $\mathrm{Fe}(\mathrm{III})$ species, responsible for a gradual deceleration 
of decontamination, thanks to the reductive photolysis of $[\mathrm{Fe}(\mathrm{OH})]^{2+}$ via reaction (8). Moreover, this enhances the $\mathrm{Fe}^{2+}$ regeneration and the production of additional amounts of ${ }^{\bullet} \mathrm{OH}[25,39]$. UVA photons can also photolyze organic intermediates like $\mathrm{Fe}(\mathrm{III})$-carboxylate complexes, originated from the destruction of aromatic pollutants, via the general reaction (9) [25, 41, 42].

$\mathrm{O}_{2}+2 \mathrm{H}^{+}+2 \mathrm{e}^{-} \rightarrow \mathrm{H}_{2} \mathrm{O}_{2}$

$\mathrm{Fe}^{2+}+\mathrm{H}_{2} \mathrm{O}_{2}+\mathrm{H}^{+} \rightarrow \mathrm{Fe}^{3+}+\cdot \mathrm{OH}+\mathrm{H}_{2} \mathrm{O}$

$[\mathrm{Fe}(\mathrm{OH})]^{2+}+h \nu \rightarrow \mathrm{Fe}^{2+}+\cdot \mathrm{OH}$

$[\mathrm{Fe}(\mathrm{OOCR})]^{2+}+h \nu \rightarrow \mathrm{CO}_{2}+\mathrm{R}^{\bullet}$

Recently, the effectiveness of the procedures described and other EAOPs like photoelectrocatalysis for the treatment of real wastewater has been discussed in several authoritative reviews [43-46].

The aim of this work is to study in depth the sequential EC/EAOP treatment of dairy wastewater, in particular whey from cheese production. The assays were performed at small $(100 \mathrm{~mL})$ and pre-pilot $(2.5-3.5 \mathrm{~L})$ scale to assess their viability. The EC pretreatment was optimized upon use of different anode/cathode pairs, including $\mathrm{Fe}, \mathrm{Al}$ and stainless steel (AISI 304 and AISI 316L) as electrodes, to achieve the maximum organic matter removal. The effluent resulting from the optimum EC was conditioned at $\mathrm{pH} 3.0$ and post-treated by PEF or EO using BDD, Pt, or DSA ${ }^{\circledR}$ ( $\mathrm{IrO}_{2}$-based and $\mathrm{RuO}_{2}$-based) as the anode to destroy the dissolved organic matter. The evolution of main physicochemical parameters of the cheese whey sample was analyzed as well.

\section{Materials and methods}

\subsection{Chemicals}

Fresh cheese whey wastewater was treated in the present work. For the application of EAOPs, the EC-pre-treated wastewater was adjusted to $\mathrm{pH} 3.0$ with analytical grade $\mathrm{HClO}_{4}$ purchased from Merck. Solutions for analysis were prepared with ultrapure water from a Millipore Milli-Q system (resistivity $>18 \mathrm{M} \Omega \mathrm{cm}$ ). The organic solvents and other chemicals were of HPLC or analytical grade from SigmaAldrich, Merck and Panreac.

\subsection{Samples of cheese whey wastewater}

The raw wastewater was obtained from a small dairy located in Lliçà d'Amunt (northeastern Spain). The sample was collected in polyethylene (HDPE) bottles and kept at $4{ }^{\circ} \mathrm{C}$ in a refrigerator prior to usage. This dairy produces daily about $1000 \mathrm{~L}$ of whey, which are currently managed using a simple physicochemical treatment (coagulation followed by filtration). Since it usually contains a high organic and mineral load that cannot be added all at once because the system would collapse, large addition of clean water to smaller volumes of whey is required. The resulting treated water is discharged into a river, whereas the sludge is buried. The usual physicochemical parameters of the raw wastewater were determined and its organic components were identified by gas chromatography-mass spectrometry (GC-MS).

\subsection{Electrochemical systems}

The electrochemical trials were performed at two scales, using either a 100-mL cell or a pre-pilot plant. The former system was used for both EC and PEF processes and consisted of an open, undivided, cylindrical glass cell, with a double jacket for circulation of external water to operate at $35^{\circ} \mathrm{C}$. In all the assays, the solution was vigorously stirred with a magnetic bar at $800 \mathrm{rpm}$. In PEF, it was also illuminated with a Philips TL/6W/08 fluorescent black light blue tube that emitted UVA light $\left(\lambda_{\max }=360 \mathrm{~nm}\right)$. Prior to PEF assays, the wastewater resulting from EC pre-treatment was conditioned by filtration to remove the sludge, followed by $\mathrm{pH}$ adjustment to 3.0 with $\mathrm{HClO}_{4}$. For the pre-pilot study, a methacrylate tank reactor containing $3.2 \mathrm{~L}$ of wastewater was used for the EC trials, made under continuous stirring at $800 \mathrm{rpm}$ with a magnetic bar at room temperature. The subsequent EO treatment was performed with $2.0 \mathrm{~L}$ of the conditioned wastewater following the procedure mentioned above, using a pre-pilot flow plant described elsewhere [39]. The electrochemical cell was connected to an annular photoreactor of $640 \mathrm{~mL}$ capacity, which contained a Philips UVA lamp of $160 \mathrm{~W}$, and the wastewater was recirculated at a flow rate of $200 \mathrm{~L} \mathrm{~h}^{-1}$ and $35^{\circ} \mathrm{C}$. All the runs were made at direct and constant $j$ provided by an Amel 2053 potentiostat-galvanostat for the small cell, and a Grelco GVD310 power supply to operate at pre-pilot scale. In the small system, some assays were carried out by reversing the polarity every $5 \mathrm{~min}$.

\subsection{Electrodes}

$\mathrm{Fe}$ (mild carbon steel), $\mathrm{Al}$ and stainless steel (AISI 304 and AISI 316L) plates of $10 \mathrm{~cm}^{2}$ of immersed area, connected in monopolar parallel configuration as one or two pairs of electrodes, were used for the EC treatments in the $100-\mathrm{mL}$ cell. The same materials, but with $140 \mathrm{~cm}^{2}$ of immersed area and always as two pairs of electrodes, were employed in the $3.2 \mathrm{~L}$ tank reactor. Before first use, all plates were mechanically abraded with $\mathrm{SiC}$ paper, cleaned with soap and acetone, and washed with Milli-Q water. Prior to each 
experiment, the electrodes were immersed in $20 \%$ (v/v) $\mathrm{H}_{2} \mathrm{SO}_{4}$ for $30 \mathrm{~s}$ to activate their surface, then cleaned with Milli-Q water in an ultrasonic bath, and finally rinsed with Milli-Q water. They were left at $90{ }^{\circ} \mathrm{C}$ for $1 \mathrm{~h}$ to reach constant weight and determine their mass.

For PEF process, the 100-mL cell was equipped with one anode of $3 \mathrm{~cm}^{2}$ area, chosen among the following ones: (i) a BDD thin-film electrode supplied by NeoCoat, synthesized by the HFCVD technique on polycrystalline $\mathrm{Si}$ wafers $(0.1 \Omega \mathrm{cm}$, Siltronix), with $700 \mathrm{ppm}$ of boron and 2.5-3.5 $\mu$ m thickness, (ii) a Pt sheet (99.99\% purity) supplied by SEMPSA, and (iii) a DSA ${ }^{\circledR}-\mathrm{O}_{2}\left(\mathrm{IrO}_{2}\right.$-based), or (iv) a $\mathrm{DSA}^{\circledR}-\mathrm{Cl}_{2}\left(\mathrm{RuO}_{2}\right.$-based) purchased from NMT Electrodes Ltd. The cathode was always a carbon-PTFE airdiffusion electrode of the same area supplied by E-TEK, mounted as in former works [40] and fed with compressed air at $1 \mathrm{~L} \mathrm{~min}^{-1}$ for $\mathrm{H}_{2} \mathrm{O}_{2}$ generation. The interelectrode gap was about $1.0 \mathrm{~cm}$. The EO treatment in the pre-pilot flow plant was performed using the same kind of BDD anode and Pt cathode, but with $20 \mathrm{~cm}^{2}$ of immersed area and separated $1.2 \mathrm{~cm}$. Before use, all the electrodes were cleaned and/or activated by electrolyzing $0.050 \mathrm{M} \mathrm{Na}_{2} \mathrm{SO}_{4}$ solutions in Milli-Q or deionized water at $j=100 \mathrm{~mA} \mathrm{~cm}^{-2}$ for $240 \mathrm{~min}$.

\subsection{Equipment and analytical procedures}

All the experiments were made in duplicate and average values with error bars related to $95 \%$ confidence interval are shown in the graphs. Samples withdrawn from the raw or treated wastewater were filtered with $0.45 \mu \mathrm{m}$ PTFE filters from Whatman or nylon filters from Filter-Lab before analysis.

The equipment and procedures for the determination of the physicochemical parameters, including $\mathrm{pH}$, conductivity, TOC, total nitrogen (TN), total suspended solids (TSS), turbidity and the concentration of metals and inorganic ions, were reported in earlier works [47, 48]. UV/Vis spectra of samples were recorded on a Shimadzu 1800 UV/Vis spectrophotometer at $25{ }^{\circ} \mathrm{C}$. The mass of electrodes before and after the $\mathrm{EC}$ processes with a stirred $\mathrm{Fe} / \mathrm{Fe}$ tank reactor at different $j$ values was measured to clarify the anodic Fe dissolution.

The organic components of the raw wastewater were identified by $\mathrm{GC}-\mathrm{MS}$ upon extraction with $\mathrm{CH}_{2} \mathrm{Cl}_{2}$, filtration of the dried sample and concentration up to ca. $1 \mathrm{~mL}$ under reduced pressure. GC-MS analysis was made with an Agilent Technologies system under conditions previously reported [49]. Polar HP INNOWax and non-polar Agilent $\mathrm{J} \& \mathrm{~W}$ HP-5 ms columns, both of $0.25 \mu \mathrm{m}, 30 \mathrm{~m} \times 0.25 \mathrm{~mm}$, were used. A NIST05 MS library was employed for the identification of the mass spectra of separated organics.

\section{Results and discussion}

\subsection{Characterization of the cheese whey wastewater}

Table 1 summarizes the physicochemical parameters determined for the raw wastewater tested. These data reveal a slightly acidic $\mathrm{pH}$ with high values of conductivity, TOC, TN, TSS, and turbidity, but low inorganic carbon (IC). $\mathrm{K}^{+}$was the most abundant cation, followed by $\mathrm{Ca}^{2+}$ and $\mathrm{Na}^{+}$, along with an insignificant amount of total Fe. High quantities of soluble $\mathrm{P}$ were detected. The predominant anion was $\mathrm{Cl}^{-}$, followed of $\mathrm{SO}_{4}{ }^{2-}$, whereas the content of $\mathrm{NO}_{3}{ }^{-}$was lower. A noticeable concentration of soluble $\mathrm{S}$ was found as well.

To gain better insight on the organic components of the sample, it was analyzed by GC-MS after extraction with $\mathrm{CH}_{2} \mathrm{Cl}_{2}$. As shown in Table 2, nine linear saturated and unsaturated carboxylic acids (fatty acids) and one steraloid, along with 2-methoxy-4-vinylphenol and benzoic acid were identified. Unfortunately, typical whey components such as proteins ( $\beta$-lactoglobulin, $\alpha$-lactalbumin, albumin bovine), lactoferrin, lactoperoxidase, lysozyme, casein, and vitamins [8], were not detected by this technique.

\subsection{Electrocoagulation in the $100-\mathrm{mL}$ cell}

Based on the large content of colloidal and particulate matter in the raw wastewater under study, EC was considered as a suitable pre-treatment method [3]. In order to optimize this process, various sets of experiments were carried out at direct $j$ of $30 \mathrm{~mA} \mathrm{~cm}^{-2}$ using a single anode/ cathode pair, upon combination of Fe, Al, AISI 304 and AISI 316L electrodes. Figure 1a-d shows the percentage of TOC removed after 30 and $60 \mathrm{~min}$ of all these treatments. The Fe anode combined with the AISI 304 cathode yielded the greatest TOC removal of $27.0 \%$ at $60 \mathrm{~min}$ (see Fig. 1a). Some trials were also performed at the same $j$ by reversing the polarity every $5 \mathrm{~min}$ for the $\mathrm{Fe} / \mathrm{Fe}, \mathrm{Al} /$ Al, AISI 304/AISI 304 and AISI 316L/AISI 316L pairs. Results of Fig. 1 evidence that, using polarity reversal, the highest TOC decay of $26.4 \%$ was achieved with the $\mathrm{Fe}$ anode, being superior to $17.4 \%$ found for the $\mathrm{Fe} / \mathrm{Fe}$ pair with no polarity change. Hence, polarity reversal turned out to be an interesting alternative to reach a high TOC removal, which can be accounted for by the destruction of the passive layer typically formed onto the Fe anode surface in monopolar connection mode. However, since the use of the AISI 304 cathode without polarity reversal was already able to ensure even a slightly better performance 
Table 1 Physicochemical characteristics of (i) raw cheese whey wastewater, (ii) sample treated under optimum EC conditions with the stirred $\mathrm{Fe} /$ AISI 304 cell at $j=30 \mathrm{~mA} \mathrm{~cm}^{-2}$ for $60 \mathrm{~min}$, (iii) EC pretreated sample followed by conditioning at $\mathrm{pH} 3.0$, and (iv) sample treated by PEF with BDD anode under $6 \mathrm{~W}$ UVA irradiation at $j=100 \mathrm{~mA} \mathrm{~cm}^{-2}$ for $420 \mathrm{~min}$

\begin{tabular}{|c|c|c|c|c|}
\hline \multirow[t]{2}{*}{ Parameter } & \multirow[t]{2}{*}{ Raw wastewater } & \multicolumn{2}{|c|}{ After EC } & \multirow[t]{2}{*}{ After PEF } \\
\hline & & Raw & Conditioned & \\
\hline $\mathrm{pH}$ & 5.64 & 7.36 & 3.00 & 1.61 \\
\hline Conductivity $\left(\mathrm{mS} \mathrm{cm}^{-1}\right)$ & 15.5 & 16.3 & 24.2 & 40.2 \\
\hline $\mathrm{TC}\left(\mathrm{mg} \mathrm{L}^{-1}\right)^{\mathrm{a}}$ & 29,833 & - & 23,533 & 23,187 \\
\hline $\mathrm{TOC}\left(\mathrm{mg} \mathrm{L}^{-1}\right)^{\mathrm{b}}$ & 29,563 & - & 21,580 & 17,147 \\
\hline $\mathrm{IC}(\mathrm{TC}-\mathrm{TOC})\left(\mathrm{mg} \mathrm{L}^{-1}\right)^{\mathrm{c}}$ & 270 & - & 1953 & 6040 \\
\hline $\mathrm{TN}\left(\mathrm{mg} \mathrm{L}^{-1}\right)^{\mathrm{d}}$ & 1106 & - & 637 & 518 \\
\hline $\operatorname{TSS}\left(\mathrm{mg} \mathrm{L}^{-1}\right)^{\mathrm{e}}$ & 5880 & 2044 & 288 & 134 \\
\hline Turbidity (NTU) & 6978 & 3482 & 270 & 55.8 \\
\hline$\left[\mathrm{Ca}^{2+}\right]\left(\mathrm{mg} \mathrm{L}^{-1}\right)$ & 545 & - & 140 & 108 \\
\hline$\left[\mathrm{Mg}^{2+}\right]\left(\mathrm{mg} \mathrm{L}^{-1}\right)$ & 79.1 & - & 27.5 & 21.4 \\
\hline$\left[\mathrm{K}^{+}\right]\left(\mathrm{mg} \mathrm{L}^{-1}\right)$ & 2076 & - & 2014 & 2014 \\
\hline$\left[\mathrm{Na}^{+}\right]\left(\mathrm{mg} \mathrm{L}^{-1}\right)$ & 484 & - & 482 & 482 \\
\hline$[\mathrm{Fe}]_{\text {total }}\left(\mathrm{mg} \mathrm{L}^{-1}\right)$ & 0.20 & - & 243 & 243 \\
\hline$[\mathrm{P}]\left(\mathrm{mg} \mathrm{L}^{-1}\right)$ & 355 & - & 10.5 & 10.5 \\
\hline$[\mathrm{Si}]\left(\mathrm{mg} \mathrm{L}^{-1}\right)$ & 1.56 & - & 2.18 & 2.18 \\
\hline$\left[\mathrm{Zn}^{2+}\right]\left(\mathrm{mg} \mathrm{L}^{-1}\right)$ & 0.20 & - & 0.92 & 0.86 \\
\hline$\left[\mathrm{NO}_{3}^{-}\right]\left(\mathrm{mg} \mathrm{L}^{-1}\right)$ & 10.8 & - & 70.7 & 0 \\
\hline$\left[\mathrm{NO}_{2}^{-}\right]\left(\mathrm{mg} \mathrm{L}^{-1}\right)$ & 0 & - & - & 0 \\
\hline$[\mathrm{S}]\left(\mathrm{mg} \mathrm{L}^{-1}\right)$ & 91.9 & - & 42.5 & 42.5 \\
\hline$\left[\mathrm{SO}_{4}{ }^{2-}\right]\left(\mathrm{mg} \mathrm{L}^{-1}\right)$ & 293 & - & 1.332 & 1.340 \\
\hline$\left[\mathrm{Cl}^{-}\right]\left(\mathrm{mg} \mathrm{L}^{-1}\right)$ & 3547 & - & 3291 & 1824 \\
\hline
\end{tabular}

${ }^{\text {a }}$ Total carbon

${ }^{\mathrm{b}}$ Total organic carbon determined as non-purgeable organic carbon

${ }^{\mathrm{c}}$ Inorganic carbon

${ }^{\mathrm{d}}$ Total nitrogen

${ }^{\mathrm{e}}$ Total suspended solids
( 27.0 vs. $26.4 \%$ ), the Fe/AISI 304 system can be considered as more convenient to increase the lifetime of the cathode, thus minimizing its periodical replacement. All the other anode/cathode arrangements led to lower TOC abatements (see Fig. 1a-d), except in the case of the Al/ AISI 304 system, which yielded $26.6 \%$ TOC abatement, similar to the $27.0 \%$ of the Fe/AISI 304 cell (see Fig. 1b). The latter pair was chosen as optimal because the Fe anode allows the generation of iron cations to be further used in Fenton-based electrochemical processes like PEF. In contrast, the two stainless steel anodes presented lower TOC decay than the Fe and $\mathrm{Al}$ ones, which can be associated with: (i) the relatively smaller production of insoluble $\mathrm{Fe}(\mathrm{OH})_{3}$, because other metals contained in them (Mo, $\mathrm{Mn}, \mathrm{Ni}$ and $\mathrm{Cr}$ ) were also dissolved, and (ii) their inherent greater resistance to corrosion with greater anodic potential than $\mathrm{Fe}$ that favors a larger current consumption to evolve $\mathrm{O}_{2}$ from water oxidation.

Table 1 reveals that after the EC treatment with the optimum Fe/AISI 304 pair, the wastewater became more alkaline, reaching $\mathrm{pH}$ 7.5. This is expected by the small production of $\mathrm{H}^{+}$from water oxidation at the anode, since it is pre-eminently dissolved to $\mathrm{Fe}^{2+}$ by reaction (1). In turn, this means that the sludge formed during EC is mainly composed of $\mathrm{Fe}(\mathrm{OH})_{3}$ with coagulated organic products. This latter aspect was confirmed by the great decrease found for TSS and turbidity (see Table 1). Note that, from the results of Fig. 1a-d, it is evident that the cathode nature has large influence on the EC performance, which is frequently disregarded in articles published on this topic. This suggests the cathodic reduction of some organic pollutants and the coagulation of the resulting products, which is promoted by the $\mathrm{Fe}(\mathrm{OH})_{3}$ flocs formed from $\mathrm{Fe}$, AISI 304 and AISI $316 \mathrm{~L}$ by reaction (3) or the $\mathrm{Al}(\mathrm{OH})_{3}$ ones formed from $\mathrm{Al}$ by reaction (4). Results of Table 1 also show a decay in $\mathrm{Cl}^{-}$concentration during EC, as revealed when the $\mathrm{pH}$ was conditioned to 3.0. This agrees with the production of strong oxidants such as active chlorine $\left(\mathrm{Cl}_{2} / \mathrm{HClO} / \mathrm{ClO}^{-}\right)$during the 60 min treatment, caused by the partial anodic oxidation of $\mathrm{Cl}^{-}$via reactions (10)-(12) [25, 41, 42, 50].

$$
\begin{aligned}
& 2 \mathrm{Cl}^{-} \rightarrow \mathrm{Cl}_{2(\mathrm{aq})}+2 \mathrm{e}^{-} \\
& \mathrm{Cl}_{2(\mathrm{aq})}+\mathrm{H}_{2} \mathrm{O} \leftrightarrows \mathrm{HClO}+\mathrm{Cl}^{-}+\mathrm{H}^{+}
\end{aligned}
$$


Table 2 Organic compounds detected in the raw cheese whey wastewater by GC-MS

\begin{tabular}{|c|c|c|c|}
\hline Compound & Molecular structure & $\begin{array}{l}\text { Retention time } \\
\quad(\min )\end{array}$ & $\begin{array}{c}\text { Main } \\
\text { fragmentation ions } \\
(\mathrm{m} / \mathrm{z})\end{array}$ \\
\hline Hexanoic acid ${ }^{\mathrm{a}}$ & & 24.394 & $116,87,73$ \\
\hline Octanoic acid ${ }^{\mathrm{a}}$ & & 28.758 & $144,101,85$ \\
\hline Sorbic acid $^{\mathrm{a}}$ & & 30.455 & $112,97,84$ \\
\hline $\begin{array}{l}\text { 2-Methoxy-4- } \\
\text { vinylphenol }^{\text {a }}\end{array}$ & & 31.274 & $150,135,118$ \\
\hline$n$-Decanoic acid & & 32.700 & $172,129,115$ \\
\hline 9-Decenoic acid ${ }^{\mathrm{a}}$ & & 33.747 & $170,152,123$ \\
\hline Benzoic acid ${ }^{\mathrm{a}}$ & & 35.309 & $122,105,77$ \\
\hline Dodecanoic acid ${ }^{\mathrm{a}}$ & & 36.305 & $200,171,157$ \\
\hline $\begin{array}{l}\text { Tetradecanoic } \\
\text { acid }^{\mathrm{a}}\end{array}$ & & 39.648 & $228,185,171$ \\
\hline $\begin{array}{l}\text { Pentadecanoic } \\
\text { acid }^{\text {a }} \\
n \text {-Hexadecanoic } \\
\text { acid }^{\mathrm{a}}\end{array}$ & & $\begin{array}{l}41.227 \\
42.763\end{array}$ & $\begin{array}{l}242,213,199 \\
256,213,157\end{array}$ \\
\hline 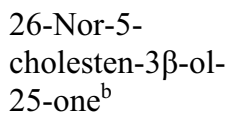 & & 53.084 & $386,368,353$ \\
\hline
\end{tabular}

$\mathrm{HClO}+\mathrm{Fe}^{2+} \rightarrow \mathrm{Fe}^{3+}+\cdot \mathrm{OH}+\mathrm{Cl}^{-}$

Several sets of experiments were made to ascertain the influence of experimental variables on the performance of the Fe/AISI 304 pair in EC, including the interelectrode gap, the number of electrode pairs used and the applied $j$ value. Figure 2 a illustrates the gradual drop in TOC removal from 27.0 to $4.9 \%$ when the distance between the electrodes grew from 1.0 to $5.0 \mathrm{~cm}$ operating with one pair of electrodes at 

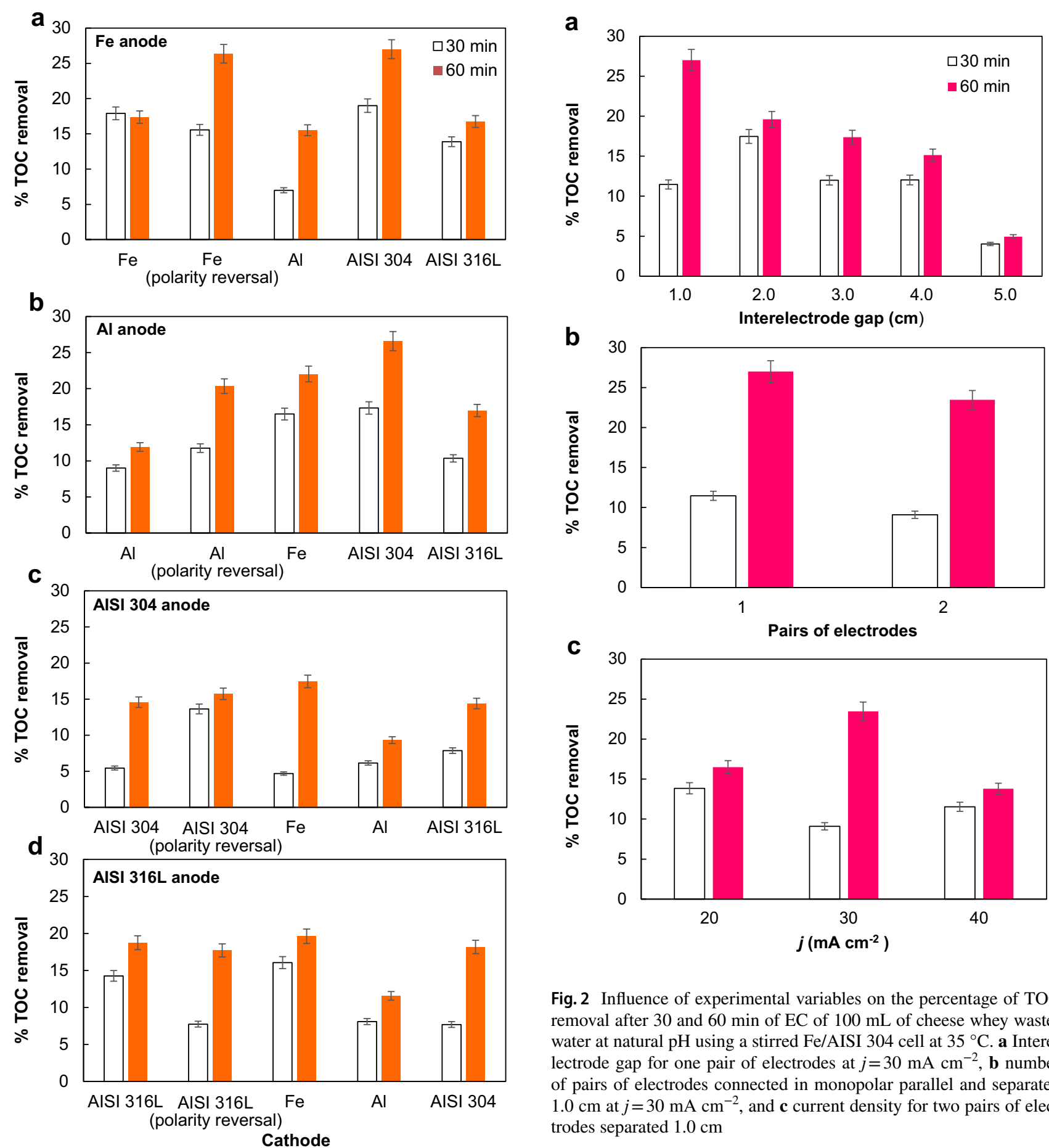

Fig. 2 Influence of experimental variables on the percentage of TOC removal after 30 and $60 \mathrm{~min}$ of $\mathrm{EC}$ of $100 \mathrm{~mL}$ of cheese whey wastewater at natural $\mathrm{pH}$ using a stirred Fe/AISI 304 cell at $35^{\circ} \mathrm{C}$. a Interelectrode gap for one pair of electrodes at $j=30 \mathrm{~mA} \mathrm{~cm}^{-2}, \mathbf{b}$ number of pairs of electrodes connected in monopolar parallel and separated $1.0 \mathrm{~cm}$ at $j=30 \mathrm{~mA} \mathrm{~cm} \mathrm{~cm}^{-2}$, and c current density for two pairs of electrodes separated $1.0 \mathrm{~cm}$

Fig. 1 Percentage of TOC removal after 30 and $60 \mathrm{~min}$ of electrocoagulation (EC) of $100 \mathrm{~mL}$ of cheese whey wastewater at natural $\mathrm{pH}$ using different stirred anode/cathode cells of $10 \mathrm{~cm}^{2}$ electrode area at current density $(j)$ of $30 \mathrm{~mA} \mathrm{~cm}{ }^{-2}$, at $35^{\circ} \mathrm{C}$. The experiments were performed with direct current and, for the cells with the same anode and cathode material, polarity reversal every $5 \mathrm{~min}$ was also tested

$j=30 \mathrm{~mA} \mathrm{~cm}{ }^{-2}$ for $60 \mathrm{~min}$. This tendency can be mainly explained by the greater ohmic drop attained as the electrode distance increases, with the consequent enhancement of the cell voltage and the acceleration of water oxidation to $\mathrm{O}_{2}$, decreasing the dissolution rate of the anode. Consequently, a lower generation of $\mathrm{Fe}(\mathrm{OH})_{3}$ flocs is achieved, thus reducing the ability to coagulate the organic matter. The distance of $1.0 \mathrm{~cm}$ was the best interelectrode gap between the $\mathrm{Fe}$ and AISI 304, being chosen for subsequent trials. 
The use of two pairs of electrodes in monopolar connection mode, instead of a single pair, was studied under the same conditions, at a distance of $1.0 \mathrm{~cm}$ and $j=30 \mathrm{~mA} \mathrm{~cm}^{-2}$. As can be seen in Fig. 2b, a small drop in TOC abatement (23.5 vs. $27.0 \%$ at $60 \mathrm{~min}$ ) occurred when the two Fe/AISI 304 pairs were utilized. This can be related to the concomitant increase of both individual cell voltages when circulating the same $j$ as in the single pair cell, thus favoring the discharge of water over Fe dissolution with formation of lower amounts of $\mathrm{Fe}(\mathrm{OH})_{3}$ flocs. Worth commenting, the system with two Fe/AISI 304 pairs seems convenient for an industrial application because each Fe anode becomes dissolved more slowly, which minimizes the replacement tasks.

Another key factor affecting the performance of EC is the applied $j$. This parameter fixes the value of the cell voltage and hence, it determines the amount of Fe dissolved as compared to the extent of the water oxidation reaction. Its influence was tested in cells with two Fe/AISI 304 pairs in monopolar connection mode, with a gap of $1.0 \mathrm{~cm}$. Figure $2 \mathrm{c}$ shows the greatest TOC removal at $j=30 \mathrm{~mA} \mathrm{~cm}^{-2}$, where the relative rate of $\mathrm{Fe}$ dissolution following reaction (1) became optimal. At a lower $j$ of $20 \mathrm{~mA} \mathrm{~cm}^{-2}$, one can expect the release of lower amounts of $\mathrm{Fe}^{2+}$ to the solution, producing smaller decays of organic pollutant concentrations owing to the smaller quantities of $\mathrm{Fe}(\mathrm{OH})_{3}$ flocs formed. More surprising, apparently, is the fact that a greater $j$ of $40 \mathrm{~mA} \mathrm{~cm}^{-2}$, where more $\mathrm{Fe}^{2+}$ is released, removes a smaller amount of organics by coagulation. This is probably due to the rapid formation of flocs with smaller average size and area, which does not favor a large aggregation of the organic matter onto their surface. These findings demonstrate that the optimum $j$ for the treatment of the raw cheese whey wastewater by EC was $30 \mathrm{~mA} \mathrm{~cm}^{-2}$ under the present experimental conditions.

\subsection{Sequential EC/PEF treatment in the $100-\mathrm{mL}$ cell}

Once the EC process was thoroughly studied, several runs were carried out by treating solutions of $100 \mathrm{~mL}$ of wastewater pre-treated under the previous optimum conditions: Fe/AISI 304 cell with the two electrodes separated $1.0 \mathrm{~cm}$, at $j=30 \mathrm{~mA} \mathrm{~cm}^{-2}$ for $60 \mathrm{~min}$. Such pre-treatment yielded suspensions that were further filtered to remove the sludge. Then, their $\mathrm{pH}$ was adjusted to 3.0 with $\mathrm{HClO}_{4}$ (to avoid changes in the $\mathrm{SO}_{4}{ }^{2-}$ and $\mathrm{Cl}^{-}$concentrations) and filtered again to obtain a clarified conditioned wastewater to be posttreated by PEF. As compared to the raw wastewater, Table 1 shows that the clarified samples presented 1.48-fold higher conductivity, along with removals of $27.0 \%$ of TOC, $42.4 \%$ of TN, $95.1 \%$ of TSS, and $96.1 \%$ of turbidity. One can also notice a large reduction of $\mathrm{Ca}^{2+}$ and $\mathrm{Mg}^{2+}$ cations, as well as of soluble $\mathrm{P}$ and $\mathrm{S}$. In contrast, the total Fe content rose from 0.20 to $243 \mathrm{mg} \mathrm{L}^{-1}$, in agreement with the release of $\mathrm{Fe}^{2+}$ ions in $\mathrm{EC}$, which is interesting to provide the iron source required for reactions (7) and (8) in PEF. Similarly, the concentration of $\mathrm{NO}_{3}{ }^{-}$and $\mathrm{SO}_{4}{ }^{2-}$ anions increased 6.5and 4.5-fold, respectively. This confirms the oxidation of $\mathrm{N}$ and S-compounds in solution or in suspended solids directly at the $\mathrm{Fe}$ anode or indirectly by active chlorine.

Figure $3 \mathrm{a}, \mathrm{b}$ exemplifies the evolution of TOC and TN removals, respectively, for the raw wastewater under optimized EC conditions for $60 \mathrm{~min}$, followed by PEF treatment of the conditioned sample using different stirred anode/ $\mathrm{O}_{2}$-diffusion cells at $j=100 \mathrm{~mA} \mathrm{~cm}^{-2}$ for $420 \mathrm{~min}$. Up to $27.0 \%$ of TOC was reduced by EC, whereas it decayed by 33.1-34.0\% using Pt or the two $\mathrm{DSA}^{\circledR}$ anodes and by $42.2 \%$ using BDD at the end of the EC/PEF sequence (see Fig. 3a). The smaller TOC removal attained by the three active anodes is indicative of a large recalcitrance of organics to the action of oxidants like ${ }^{\bullet} \mathrm{OH}$ and active chlorine ( $\mathrm{HClO})$ in the bulk, as well as to photolysis by UVA radiation. The superior oxidation ability of the non-active BDD

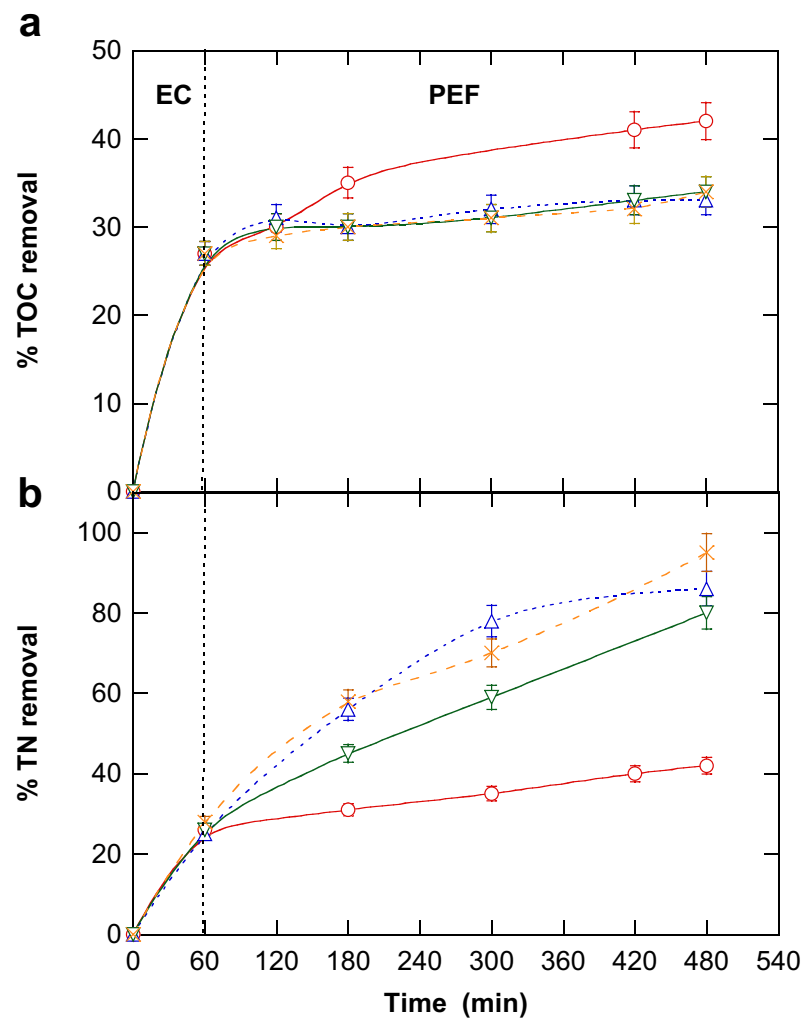

Fig. 3 Time course of the percentage of a TOC and $\mathbf{b}$ TN removals for the sequential EC/photoelectro-Fenton (PEF) treatment of $100 \mathrm{~mL}$ of cheese whey wastewater at $35{ }^{\circ} \mathrm{C}$. The EC treatment was carried out at natural $\mathrm{pH}$ using an optimum stirred Fe/AISI 304 cell at $j=30 \mathrm{~mA} \mathrm{~cm}{ }^{-2}$ for $60 \mathrm{~min}$. After conditioning the filtered wastewater at $\mathrm{pH} 3.0$, the PEF treatment using a 6-W UVA lamp was made with a stirred cell equipped with a (circle) boron-doped diamond (BDD), (triangle) $\mathrm{Pt}$, (inverted triangle) $\mathrm{IrO}_{2}$-based, or (diagonal cross) $\mathrm{RuO}_{2}$-based anode and an air-diffusion cathode, all of $3 \mathrm{~cm}^{2}$ area, at $j=100 \mathrm{~mA} \mathrm{~cm}^{-2}$ and $35^{\circ} \mathrm{C}$ for $420 \mathrm{~min}$ 
can be related to the parallel quicker attack of the powerful $\mathrm{BDD}\left({ }^{\bullet} \mathrm{OH}\right)$ originated from reaction $(5)[17,18]$ on organics, enhancing the mineralization process.

A very different behavior can be observed in Fig. 3b for the TN decay. This parameter was largely removed with the three active anodes, especially in the cell with the $\mathrm{RuO}_{2}$-based anode that yielded $95.2 \%$ abatement, being less effective the PEF treatment with BDD with only $41.5 \%$ removal. These findings suggest an important role of oxidants like active chlorine, formed more largely with active anodes [31, 32], to destroy the $\mathrm{N}$-compounds and giving rise to volatile products like $\mathrm{N}_{2}$ and $\mathrm{N}_{\mathrm{x}} \mathrm{O}_{\mathrm{y}}$ species [40-42], and volatile chloramines [52]. The last column of Table 1 shows the overall disappearance of $\mathrm{NO}_{3}{ }^{-}$during the PEF process with BDD, which can be related to its photoreduction to $\mathrm{NO}_{2}{ }^{-}$followed by its decomposition to $\mathrm{N}_{\mathrm{x}} \mathrm{O}_{\mathrm{y}}$ [53]. Similarly, the $\mathrm{Cl}^{-}$concentration was reduced by $44.6 \%$, thus corroborating the oxidation of this ion with formation of active chlorine from reactions $(10)$ and (11). The attack of $\operatorname{BDD}\left({ }^{\bullet} \mathrm{OH}\right)$ and ${ }^{\circ} \mathrm{OH}$ onto organics generated acidic products, leading to the acidification of the treated sample with a final $\mathrm{pH}=1.61$, in concomitance with an increase in conductivity up to 40.2 $\mathrm{mS} \mathrm{cm} \mathrm{c}^{-1}$ (see Table 1). The data of Table 1 also show a significant drop in TSS and turbidity due to the degradation of their components by all the above oxidants. Conversely, no significant change in the concentration of the other ions and soluble $\mathrm{S}, \mathrm{P}$ and total Fe was found.

The change in sample color during the sequential EC/ PEF treatment is depicted in Fig. 4a. The raw cheese whey wastewater had a whitish appearance due to its high TSS concentration and turbidity, whereas it became dark during EC with a sludge floating on surface. After conditioning, the sample acquired again a whitish color with a turbid appearance, which disappeared in PEF. At the end, a transparent yellow-brown sample was obtained, mainly by the presence of Fe ions in solution. Figure $4 \mathrm{~b}$ illustrates the UV/Vis spectra recorded for the raw and final wastewater. A high absorbance of the raw wastewater within the $\lambda$ region from 200 to $300 \mathrm{~nm}$ can be observed, as expected from a colorless effluent with a large content of carboxylic and aromatic pollutants. The absence of most aromatics in the final wastewater upon sequential electrochemical treatment explains the high decrease in absorbance in such region.

\subsection{Electrocoagulation at pre-pilot scale}

The study of the sequential electrochemical treatment was extended to pre-pilot scale. A set of EC experiments was performed with $3.2 \mathrm{~L}$ of the raw wastewater in a stirred tank reactor equipped with two pairs of electrodes separated $1.0 \mathrm{~cm}$ and connected in monopolar mode. The anode chosen was a Fe plate of $140 \mathrm{~cm}^{2}$ area, since it was found the best material for EC and subsequent EAOP post-treatment
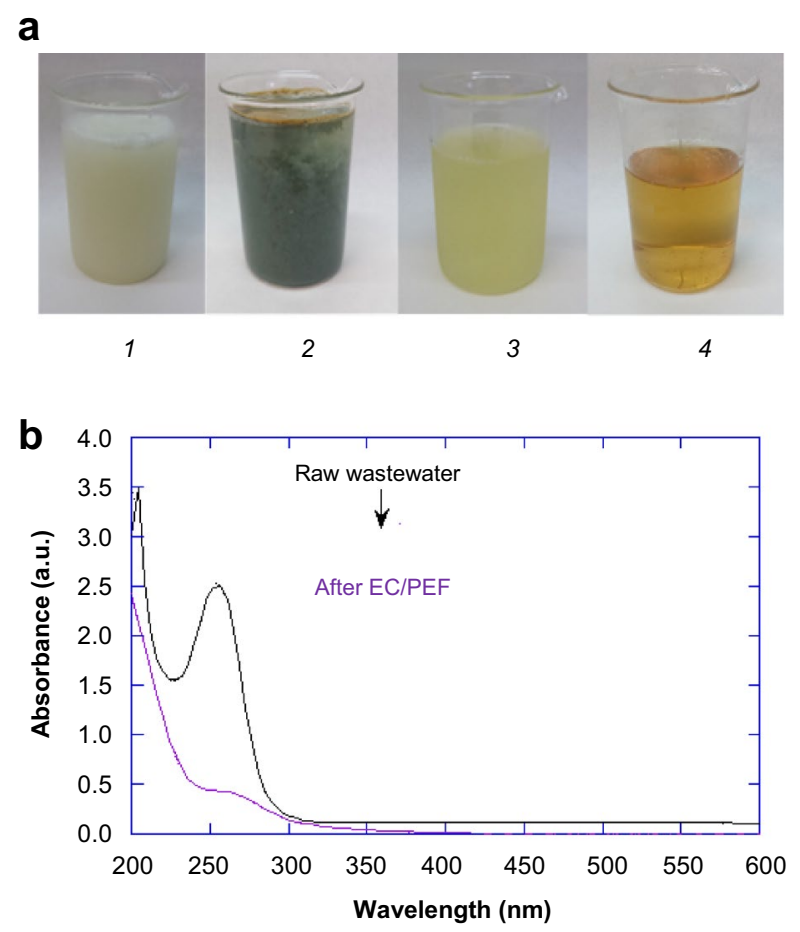

Fig. 4 a Photographs during tests shown in Fig. 3. 1 Raw wastewater, along with samples withdrawn after $2 \mathrm{EC}, 3 \mathrm{EC}+$ conditioning at $\mathrm{pH}$ 3.0, and $4 \mathrm{PEF}$ with BDD anode. $\mathbf{b} \mathrm{UV} / \mathrm{Vis}$ spectra of the wastewater before and after the sequential EC/PEF (BDD) treatment of Fig. 3

(see previous subsection). Figure 5a shows the percentage of TOC removal after 30 and $60 \mathrm{~min}$ using two $\mathrm{Fe} / \mathrm{Fe}$ pairs at $j$ values from 5 to $40 \mathrm{~mA} \mathrm{~cm}{ }^{-2}$. As can be seen, greater TOC was removed, attaining $22.1 \%$, at $j=30 \mathrm{~mA} \mathrm{~cm}^{-2}$, as a result of the progressively faster dissolution of the two anodes from reaction (1) at raising $j$. However, it decayed to $19.3 \%$ at the highest $j=40 \mathrm{~mA} \mathrm{~cm}{ }^{-2}$, probably due to the formation of smaller flocs with lower ability for organic matter adsorption, as stated above. This trend was also obtained for two Fe/AISI 304 pairs at 100-mL scale (see Fig. 2c). After these trials, it was confirmed that the mass lost by the Fe anodes was of 100, 198, 393, 585 and $774 \mathrm{mg}$ at increasing $j$ from 5 to $40 \mathrm{~mA} \mathrm{~cm}^{-2}$. This means that it decreased slightly from 96.2 to $93.0 \%$, as compared to the theoretical values assuming the Faraday's law for reaction (1). These results inform about the pre-eminent anodic reaction of $\mathrm{Fe}$ to $\mathrm{Fe}^{2+}$ in all cases, being much less important the water oxidation to $\mathrm{O}_{2}$, although this parasitic reaction was gradually accelerated as $j$ was risen.

From the above findings, one can infer again that the best $j$ for the EC treatment of the raw wastewater was $30 \mathrm{~mA} \mathrm{~cm}^{-2}$. The effect of the cathode material on the EC performance was verified at this scale. Figure $5 \mathrm{~b}$ shows that after 60 min of electrolysis, 13.5, 22.0 and $12.1 \%$ of TOC was abated using an Al, AISI 304 and AISI 316L 


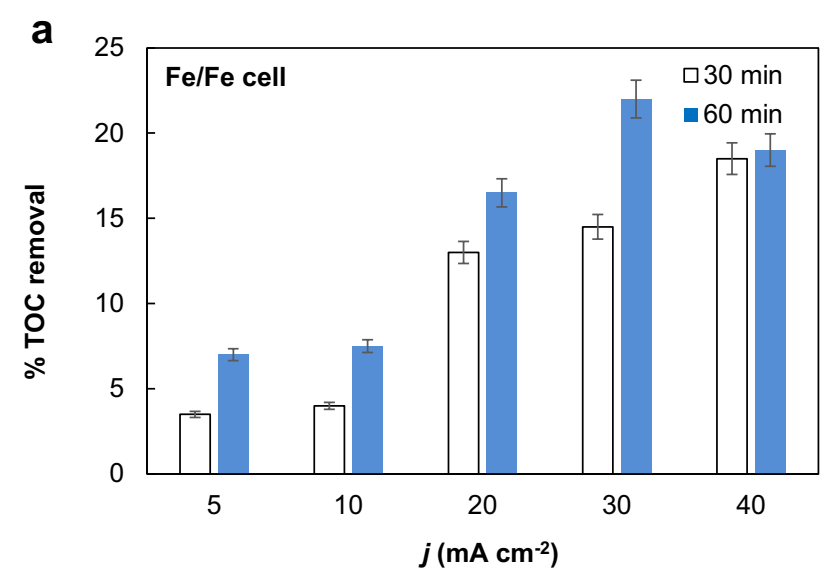

b

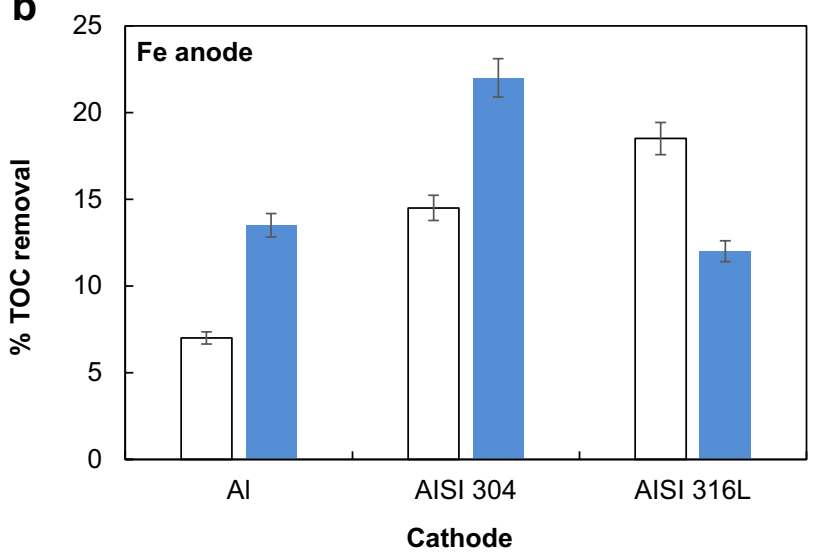

Fig. 5 Percentage of TOC removal after 30 and 60 min of EC treatment of $3.2 \mathrm{~L}$ of a raw cheese whey wastewater at natural $\mathrm{pH}$ using a stirred $\mathrm{Fe} /$ cathode tank reactor with two pairs of electrodes of $140 \mathrm{~cm}^{2}$ area each, separated $1.0 \mathrm{~cm}$ at room temperature. a Effect of current density with Fe cathodes. $\mathbf{b}$ Comparison of performance with $\mathrm{Al}$, AISI 304, and AISI $316 \mathrm{~L}$ cathodes at $j=30 \mathrm{~mA} \mathrm{~cm}^{-2}$

cathode, respectively. This confirms the aforementioned large influence of the cathode on the EC performance. Our results evidence the greatest TOC removal using the $\mathrm{Fe} / \mathrm{Fe}$ and Fe/AISI 304 cells at the optimum $j=30 \mathrm{~mA}$ $\mathrm{cm}^{-2}$, as also found at $100-\mathrm{mL}$ scale (see Fig. 1). In both cases, the $\mathrm{pH}$ of the samples became more alkaline, up to $6.1-6.4$, and their conductivity grew $<10 \%$, but the corresponding $\mathrm{TN}$ decayed by 51.0 and $59.0 \%$, respectively. As in the case of the $100-\mathrm{mL}$ scale, the use of the AISI 304 cathode is interesting for EC. It presents an analogous behavior as compared to the Fe one, but it has greater corrosion resistance and requires lower maintenance. This cathode was chosen for the next study about the sequential electrochemical treatment of the raw wastewater.

\subsection{Sequential EC/EAOP treatment at pre-pilot scale}

The previous study at $100-\mathrm{mL}$ scale allowed concluding that BDD is the best anode for the PEF post-treatment of

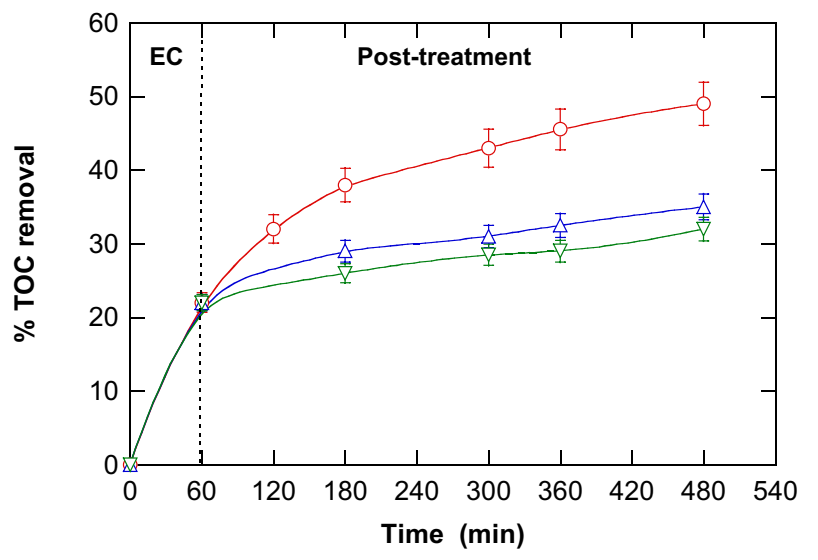

Fig. 6 Percentage of TOC removal with electrolysis time for the sequential EC/electrochemical oxidation (EO) treatment of cheese whey wastewater at $35{ }^{\circ} \mathrm{C}$. The EC treatment of $3.2 \mathrm{~L}$ of wastewater at natural $\mathrm{pH}$ was performed with the Fe/AISI 304 tank reactor under the conditions of Fig. $5 \mathrm{~b}$ for $60 \mathrm{~min}$. After that, $2.0 \mathrm{~L}$ of filtered EC-treated wastewater were conditioned at $\mathrm{pH} 3.0$ and treated in a pre-pilot flow plant equipped with a BDD/Pt cell of $20 \mathrm{~cm}^{2}$ electrode area, at $j=50 \mathrm{~mA} \mathrm{~cm}{ }^{-2}$, liquid flow rate of $200 \mathrm{~L} \mathrm{~h}^{-1}$ and $35^{\circ} \mathrm{C}$ for $480 \mathrm{~min}$. The cell was connected to an annular photoreactor of $640 \mathrm{~mL}$ capacity containing a $160 \mathrm{~W}$ UVA lamp. (Circle) EO with UVA light, (triangle) EO and (inverted triangle) UVA light alone

the conditioned wastewater obtained in EC. The superior, but low TOC removal attained after PEF with a BDD/airdiffusion cell (42.2\%) after $420 \mathrm{~min}$ at $j=100 \mathrm{~mA} \mathrm{~cm}^{-2}$ (see Fig. 3a) can be explained by a much greater oxidative role of $\operatorname{BDD}\left({ }^{\circ} \mathrm{OH}\right)$ compared to ${ }^{\circ} \mathrm{OH}$ and active chlorine during the EAOP. Based on this, the coupling of EC with EO without and with UVA radiation was explored at pre-pilot scale. Note that the scale-up from $100 \mathrm{~mL}$ for an electrochemical process is complicated, not just because of the increment of the volume to be treated, but due to the influence of the geometry of electrodes and cell, as well as the hydrodynamics of the system related to the mass transport and the potential distribution, among other parameters.

First, 3.2 L of wastewater were electrolyzed for $60 \mathrm{~min}$ using a tank equipped with two Fe/AISI 304 pairs at $j=30 \mathrm{~mA} \mathrm{~cm}^{-2}$. After that, the resulting sample was conditioned by filtration $+\mathrm{pH}$ adjustment to 3.0 with $\mathrm{HClO}_{4}+$ filtration to operate under the same conditions as optimum $\mathrm{PEF}$, and $2.0 \mathrm{~L}$ were introduced in the reservoir of the prepilot flow plant and recirculated through it at a flow rate of $200 \mathrm{~L} \mathrm{~h}^{-1}$ keeping its temperature at $35{ }^{\circ} \mathrm{C}$. The liquid circulated through a BDD/Pt cell (without $\mathrm{H}_{2} \mathrm{O}_{2}$ generation) coupled to an annular photoreactor containing a $160 \mathrm{~W}$ UVA lamp. Figure 6 shows the TOC removed by EO with UVA irradiation at $j=50 \mathrm{~mA} \mathrm{~cm}^{-2}$ and blank experiments. After 480 min of treatment in batch, the percentage of total TOC removal (also including the $22.0 \%$ obtained in EC) was $31.5,35.2$, and $49.1 \%$ upon UVA photolysis, EO, and 
UVA-photoassisted EO, respectively. The contribution of UVA light to TOC decay (i.e., 9.5\%) suggests the mineralization of $\mathrm{Fe}(\mathrm{III})$-carboxylate complexes present in the wastewater by photodecarboxylation, according to reaction (9). The $13.2 \%$ of TOC abatement arising upon EO treatment confirms the oxidative action of $\operatorname{BDD}\left({ }^{\circ} \mathrm{OH}\right)$ and, to a smaller extent, of active chlorine on organic pollutants. The $27.1 \%$ of TOC removal obtained at the end of EO with UVA light was slightly higher than the sum of $22.7 \%$ of the two individual processes, meaning that a synergistic effect between oxidation and photolysis is feasible when the hybrid EAOP is applied.

Finally, the specific energy consumption per unit TOC mass $\left(\mathrm{EC}_{\mathrm{TOC}}\right.$, in $\left.\mathrm{kWh}(\mathrm{kg} \mathrm{TOC})^{-1}\right)$ for the above sequential electrochemical treatment was evaluated as follows [24, 25]:

$\mathrm{EC}_{\mathrm{TOC}}=\frac{1000 E_{\mathrm{cell}} I t}{V \Delta(\mathrm{TOC})_{\exp }}$

where 1000 is a factor to homogenize units $\left(\mathrm{mg} \mathrm{g}^{-1}\right), E_{\text {cell }}$ is the average cell voltage (in $\mathrm{V}$ ), $I$ is the applied current (in A), $t$ is the electrolysis time (in h), $V$ is the volume of treated wastewater (in L) and $\Delta$ (TOC) $_{\exp }$ is the TOC abated (in $\mathrm{m} \mathrm{L} \mathrm{L}^{-1}$ ). In the case of the EC pre-treatment for $1 \mathrm{~h}$ $\left(E_{\text {cell }}=8.3 \mathrm{~V}\right.$ and $\left.I=8.40 \mathrm{~A}\right)$, a low $\mathrm{EC}_{\mathrm{TOC}}=3.36 \mathrm{kWh}$ $(\mathrm{kg} \mathrm{TOC})^{-1}$ was found. A greater $\mathrm{EC}_{\mathrm{TOC}}=14.78 \mathrm{kWh}(\mathrm{kg}$ TOC $)^{-1}$ after the $8 \mathrm{~h}$ of EO $\left(E_{\text {cell }}=11.4 \mathrm{~V}\right.$ and $\left.I=1.0 \mathrm{~A}\right)$ was needed. This value increased extraordinarily to $192.16 \mathrm{kWh}$ $(\mathrm{kg} \mathrm{TOC})^{-1}$ when only UVA illumination was employed, due to the high power of the lamp $(160 \mathrm{~W})$. This explains the high $\mathrm{EC}_{\mathrm{TOC}}=109.77 \mathrm{kWh}(\mathrm{kg} \mathrm{TOC})^{-1}$ determined for the most effective post-treatment, i.e., EO with UVA light. To obtain a cost-effective process at industrial level is then necessary to replace the artificial light by a free energy source like sunlight, which has been well-proven to be very efficient for solar Fenton-based electrochemical processes [25, 39].

\section{Conclusions}

AISI 304 is the most suitable cathode material for the decontamination of cheese whey wastewater at natural $\mathrm{pH}$ by EC at small and large scales. Its combination with a Fe anode yields greater TOC removal as compared to cells with $\mathrm{Al}$ or stainless steels anodes, which is beneficial for the posttreatment with EAOPs. However, only $22.0-27.0 \%$ of TOC was removed using one or two Fe/AISI 304 pairs at optimal interelectrode gap of $1.0 \mathrm{~cm}$ and $j=30 \mathrm{~mA} \mathrm{~cm}^{-2}$ for $60 \mathrm{~min}$ at both scales. Coagulation of organics onto the $\mathrm{Fe}(\mathrm{OH})_{3}$ flocs, reduction at the cathode or oxidation with active chlorine explain the decay in TOC, TN, TSS and turbidity. The post-treatment of the EC-treated wastewater, conditioned at $\mathrm{pH} 3.0$, by PEF at $100-\mathrm{mL}$ scale showed the highest TOC removal using a non-active BDD anode, because of the high oxidation power of $\mathrm{BDD}\left({ }^{\bullet} \mathrm{OH}\right)$. In contrast, the TN decayed much more rapidly with active anodes because of the effective attack of active chlorine onto N-compounds. At prepilot scale, the conditioned wastewater was post-treated by UVA-photoassisted EO with a BDD/Pt flow cell, leading to the greatest total TOC removal of $49.1 \%$ after $480 \mathrm{~min}$ at $j=50 \mathrm{~mA} \mathrm{~cm}^{-2}$. This was ascribed to the synergistic oxidation of $\mathrm{BDD}\left({ }^{\circ} \mathrm{OH}\right)$ and photolysis. The low energy consumptions found for the sequential EC/EO treatment increased significantly when the UVA lamp power was computed and hence, sunlight-assisted EO would be more suitable for a cost-effective sequential electrochemical treatment at industrial scale.

Acknowledgements The authors acknowledge financial support from project CTQ2016-78616-R (AEI/FEDER, EU). Dr. Ömür Gökkuş would like to thank for the support to the Scientific and Technological Research Council of Turkey (TUBITAK) 2219 - International Post-Doctoral Research Fellowship Programme (Grant Number 1059B191601343).

\section{References}

1. Hoekstra AY (2010) The water footprint of animal products. In: D'Silva J, Webster J (eds) The meat crisis: developing more sustainable production and consumption. Earthscan, London, pp 22-33

2. Balannec B, Vourch M, Rabiller-Baudry M, Chaufer B (2005) Comparative study of different nanofiltration and reverse osmosis membranes for dairy effluent treatment by dead-end filtration. Sep Purif Technol 42:195-200

3. Borbón B, Oropeza-Guzman MT, Brillas E, Sirés I (2014) Sequential electrochemical treatment of dairy wastewater using aluminum and DSA-type anodes. Environ Sci Pollut Res 21:8573-8584

4. Demirel B, Yenigun O, Onay TT (2005) Anaerobic treatment of dairy wastewaters: a review. Process Biochem 40:2583-2595

5. Prazeres AR, Carvalho F, Rivas J (2012) Cheese whey management: a review. J Environ Manag 110:48-68

6. Qasim W, Mane AV (2013) Characterization and treatment of selected food industrial effluents by coagulation and adsorption techniques. Water Resour Ind 4:1-12

7. Haridas A, Suresh S, Chitra KR, Manilal VB (2005) The Buoyant Filter Bioreactor: a high-rate anaerobic reactor for complex wastewater-process dynamics with dairy effluent. Water Res 39:993-1004

8. Rico JL, García H, Rico C, Tejero I (2007) Characterisation of solid and liquid fractions of dairy manure with regard to their component distribution and methane production. Bioresour Technol 98:971-979

9. Amini M, Younesi H, Lorestani AAZ, Najafpour G (2013) Determination of optimum conditions for dairy wastewater treatment in UAASB reactor for removal of nutrients. Bioresour Technol 145:71-79

10. Wen J, Tao W, Wang Z, Pei Y (2013) Enhancing simultaneous nitritation and anammox in recirculating biofilters: effects of unsaturated zone depth and alkalinity dissolution of packing materials. J Hazard Mater 244-245:671-680 
11. Katsoni A, Mantzavinos D, Diamadopoulos E (2014) Coupling digestion in a pilot-scale UASB reactor and electrochemical oxidation over BDD anode to treat diluted cheese whey. Environ Sci Pollut Res 21:12170-12181

12. Hamdani A, Mountadar M, Assobhei O (2005) Comparative study of the efficacy of three coagulants in treating dairy factory waste water. Int J Dairy Technol 58:83-88

13. Prazeres AR, Carvalho F, Rivas J (2013) Fenton-like application to pretreated cheese whey wastewater. J Environ Manag 129:199-205

14. Smoczynski L, Munska K, Pierozynski B (2013) Electrocoagulation of synthetic dairy wastewater. Water Sci Technol 67:404-409

15. Sharma D (2014) Treatment of dairy wastewater by electrocoagulation using aluminum electrodes and settling, filtration studies. Int J ChemTech Res 6:591-599

16. Un UT, Kandemir A, Erginel N, Eren Ocal S (2014) Continuous electrocoagulation of cheese whey wastewater: an application of response surface methodology. J Environ Manag 146:245-250

17. Varank G, Sabuncu ME (2015) Application of Central Composite Design approach for dairy wastewater treatment by electrocoagulation using iron and aluminum electrodes: modeling and optimization. Desalin Water Treat 56:33-54

18. Benazzi TL, Dallago RM, Steffens J, Mores R, Do Nascimento MS, Krebs J, Ceni G, Di Luccio M (2016) Continuous flow electrocoagulation in the treatment of wastewater from dairy industries. Water Sci Technol 73:1418-1425

19. Davarnejad R, Nikseresht M (2016) Dairy wastewater treatment using an electrochemical method: experimental and statistical study. J Electroanal Chem 775:364-373

20. Torres-Sánchez AL, López-Cervera SJ, de la Rosa C, Maldonado-Vega M, Maldonado-Santoyo M, Peralta-Hernández JM (2014) Electrocoagulation process coupled with advance oxidation techniques to treatment of dairy industry wastewater. Int J Electrochem Sci 9:6103-6112

21. Bensadok K, El Hanafi N, Lapicque F (2011) Electrochemical treatment of dairy effluent using combined $\mathrm{Al}$ and $\mathrm{Ti} / \mathrm{Pt}$ electrodes system. Desalination 280:244-251

22. Markou V, Kontogianni MC, Frontistis Z, Tekerlekopoulou AG, Katsaounis A, Vayenas D (2017) Electrochemical treatment of biologically pre-treated dairy wastewater using dimensionally stable anodes. J Environ Manag 202:217-224

23. Panizza M, Cerisola G (2009) Direct and mediated anodic oxidation of organic pollutants. Chem Rev 109:6541-6569

24. Sirés I, Brillas E, Oturan MA, Rodrigo MA, Panizza M (2014) Electrochemical advanced oxidation processes: today and tomorrow. A review. Environ Sci Pollut Res 21:8336-8367

25. Brillas E, Martínez-Huitle CA (2015) Decontamination of wastewaters containing synthetic organic dyes by electrochemical methods. An updated review. Appl Catal B 166-167:603-643

26. Martínez-Huitle CA, Rodrigo MA, Sirés I, Scialdone O (2015) Single and coupled electrochemical processes and reactors for the abatement of organic water pollutants: a critical review. Chem Rev 115:13362-13407

27. Mollah MYA, Morkovsky P, Gomes JAG, Kesmez M, Parga J, Cocke DL (2004) Fundamentals, present and future perspectives of electrocoagulation. J Hazard Mater B114:199-210

28. Irdemez S, Demircioğlu N, Yildiz YS, Bingül Z (2006) The effects of current density and phosphate concentration on phosphate removal from wastewater by electrocoagulation using aluminum and iron plate electrodes. Sep Purif Technol 52:218-223

29. Un UT, Ozel E (2013) Electrocoagulation of yogurt industry wastewater and the production of ceramic pigments from the sludge. Sep Purif Technol 120:386-391
30. Song P, Yang Z, Xu H, Huang J, Yang X, Wang L (2014) Investigation of influencing factors and mechanism of antimony and arsenic removal by electrocoagulation using $\mathrm{Fe}-\mathrm{Al}$ electrodes. Ind Eng Chem Res 53:12911-12919

31. Coria G, Sirés I, Brillas E, Nava JL (2016) Influence of the anode material on the degradation of naproxen by Fenton-based electrochemical processes. Chem Eng J 304:817-825

32. Steter JR, Brillas E, Sirés I (2016) On the selection of the anode material for the electrochemical removal of methylparaben from different aqueous media. Electrochim Acta 222:1464-1474

33. Galia A, Lanzalaco S, Sabatino MA, Dispenza C, Scialdone O, Sirés I (2016) Crosslinking of poly(vinylpyrrolidone) activated by electrogenerated hydroxyl radicals: a first step towards a simple and cheap synthetic route of nanogel vectors. Electrochem Commun 62:64-68

34. Labiadh L, Barbucci A, Carpanese MP, Gadri A, Panizza M (2016) Comparative depollution of Methyl Orange aqueous solutions by electrochemical incineration using $\mathrm{TiRuSnO}_{2}, \mathrm{BDD}$ and $\mathrm{PbO}_{2}$ as high oxidation power anodes. J Electroanal Chem 766:94-99

35. Oturan MA, Pimentel M, Oturan N, Sirés I (2008) Reaction sequence for the mineralization of the short-chain carboxylic acids usually formed upon cleavage of aromatics during electrochemical Fenton treatment. Electrochim Acta 54:173-182

36. Çelebi MS, Oturan N, Zazou H, Hamdani M, Oturan MA (2015) Electrochemical oxidation of carbaryl on platinum and borondoped diamond anodes using electro-Fenton technology. Sep Purif Technol 156:996-1002

37. Ammar S, Oturan MA, Labiadh L, Guersalli A, Abdelhedi R, Oturan N, Brillas E (2015) Degradation of tyrosol by a novel electro-Fenton process using pyrite as heterogeneous source of iron catalyst. Water Res 74:77-87

38. Sopaj F, Oturan N, Pinson J, Podvorica F, Oturan MA (2016) Effect of the anode materials on the efficiency of the electro-Fenton process for the mineralization of the antibiotic sulfamethazine. Appl Catal B 199:331-341

39. Flox C, Garrido JA, Rodríguez RM, Cabot PL, Centellas F, Arias C, Brillas E (2007) Mineralization of herbicide mecoprop by photoelectro-Fenton with UVA and solar light. Catal Today 129:29-36

40. Guinea E, Garrido JA, Rodríguez RM, Cabot PL, Arias C, Centellas F, Brillas E (2010) Degradation of the fluoroquinolone enrofloxacin by electrochemical advanced oxidation processes based on hydrogen peroxide electrogeneration. Electrochim Acta 55:2101-2115

41. Thiam A, Zhou M, Brillas E, Sirés I (2014) A first pre-pilot system for the combined treatment of dye pollutants by electrocoagulation/EAOPs. J Chem Technol Biotechnol 89:1136-1144

42. Thiam A, Zhou M, Brillas E, Sirés I (2014) Two-step mineralization of Tartrazine solutions: study of parameters and by-products during the coupling of electrocoagulation with electrochemical advanced oxidation processes. Appl Catal B 150-151:116-125

43. Peralta-Hernández JM, Méndez-Tovar M, Guerra-Sánchez R, Martínez-Huitle CA, Nava JL (2012) A brief review on environmental application of boron doped diamond electrodes as a new way for electrochemical incineration of synthetic dyes. Int J Electrochem 154316:18 pp

44. Sirés I, Brillas E (2012) Remediation of water pollution caused by pharmaceutical residues based on electrochemical separation and degradation technologies-a review. Environ Int 40:212-229

45. Moreira FC, Boaventura RAR, Brillas E, Vilar VJP (2017) Electrochemical advanced oxidation processes: a review on their application to synthetic and real wastewater. Appl Catal B 202:217-261

46. Garcia-Segura S, Brillas E (2017) Applied photoelectrocatalysis on the degradation of organic pollutants in wastewaters. J Photochem Photobiol C 31:1-35 
47. Flores N, Cabot PL, Centellas F, Garrido JA, Rodríguez RM, Brillas E, Sirés I (2017) 4-Hydroxyphenylacetic acid oxidation in sulfate and real olive oil mill wastewater by electrochemical advanced processes with a boron-doped diamond anode. J Hazard Mater 321:566-575

48. Flores N, Brillas E, Centellas F, Rodríguez RM, Cabot PL, Garrido JA, Sirés I (2018) Treatment of olive oil mill wastewater by single electrocoagulation with different electrodes and sequential electrocoagulation/electrochemical Fenton-based processes. J Hazard Mater 347:58-66

49. Thiam A, Brillas E, Garrido JA, Rodríguez RM, Sirés I (2016) Routes for the electrochemical degradation of the artificial food azo-colour Ponceau 4R by advanced oxidation processes. Appl Catal B 180:227-236

50. Bocos E, Brillas E, Sanromán MA, Sirés I (2016) Electrocoagulation: simply a phase separation technology? The case of bronopol compared to its treatment by EAOPs. Environ Sci Technol 50:7679-7686

51. Aguilar ZG, Brillas E, Salazar M, Nava JL, Sirés I (2017) Evidence of Fenton-like reaction with active chlorine during the electrocatalytic oxidation of Acid Yellow 36 azo dye with Ir-Sn-Sb oxide anode in the presence of iron ion. Appl Catal B 206:44-52

52. Cotillas S, Llanos J, Castro-Ríos K, Taborda-Ocampo G, Rodrigo MA, Cañizares P (2016) Synergistic integration of sonochemical and electrochemical disinfection with DSA anodes. Chemosphere 163:562-568

53. Sharpless CM, Linden KG (2001) UV Photolysis of nitrate: effects of natural organic matter and dissolved inorganic carbon and implications for UV water disinfection. Environ Sci Technol 35:2949-2955

\section{Affiliations}

\section{Lydia Tirado $^{1}$. Ömür Gökkuş ${ }^{2}$ Enric Brillas ${ }^{1} \cdot$ Ignasi Sirés $^{1}$}

1 Laboratori d'Electroquímica dels Materials i del Medi Ambient, Departament de Química Física, Facultat de Química, Universitat de Barcelona, Martí i Franquès 1-11, 08028 Barcelona, Spain
2 Department of Environmental Engineering, Erciyes University, 38039 Kayseri, Turkey 